STUDIA PRAWNO-EKONOMICZNE, t. CV, 2017

PL ISSN 0081-6841; e-ISSN 2450-8179 s. 125-147

DOI: 10.26485/SPE/2017/105/8

Marek WASIŃSKI*

\title{
THE OPTIONAL DECLARATIONS REGIME AS A LAWFUL TOOL TO DEVELOP THE JURISPRUDENTIAL INTERACTION BETWEEN THE AFRICAN COURT ON HUMAN AND PEOPLES' RIGHTS AND THE NATIONAL AUTHORITIES
}

\begin{abstract}
(Summary)
The starting point for this paper is the problem of limited individual access to the African Court on Human and Peoples' Rights under Article 5(3) and Article 34(6) of the Protocol to the African Charter on Human and Peoples' Rights on the Establishment of the Court. While such a restriction imposed upon its personal jurisdiction is a standard element of political constraint introduced by states to protect their interests, it is argued that the aforementioned provisions may be also perceived differently, namely as constituting a platform enabling dialogue between the judicial organ and the sovereigns. It is asserted in particular that judges of the Court may stimulate expansion of the individual access striking a fair balance between the tendency to interpret human rights obligations of the states progressively and the relevant policy considerations echoing the more conservative approach in their perception of human rights. The paper presents such a judicial tactic as reflecting a particular environment of the international society and possibly remaining in line with international law of treaty interpretation and judicial impartiality.
\end{abstract}

Keywords: human rights in Africa; impartiality of international judges; independence of international courts

\section{Introduction}

The African Court on Human and Peoples' Rights (ACtHPR) was formally established in 2004 as the last one out of the three regional international human rights tribunals ${ }^{1}$. The ACtHPR is vested with contentious and advisory jurisdiction that

* Senior Lecturer, University of Lodz, Faculty of Law and Administration, Department of International Law and International Relations; e-mail: marek.wasinski@gmail.com

1 At present, the European and Inter-American regional systems also allow cases to be heard by a permanent international courts: The European Court of Human Rights (ECtHR) established 
complements ${ }^{2}$ the protective mandate of the African Commission on Human and Peoples' Rights (ACmHPR) - the pre-existing quasi-judicial body. In particular, the ACtHPR as a judicial organ is entitled to give final and binding judgments enforceable by the organs of the African Union (AU) and if it finds that there has been a violation of human or peoples' right, it shall issue appropriate orders to remedy the violation including payment of fair compensation or reparation ${ }^{3}$. Therefore, from the theoretical standpoint, the establishment of the ACtHPR clearly advances non-arbitrariness in the exercise of sovereign powers. It endorses law-obedience and hence promotes the international rule of law.

However, its practical contribution thereupon seems to be significantly diminished by the limited individual access to its judicial function. The Protocol to the African Charter on Human and Peoples' Rights on the Establishment of the ACtHPR (the Protocol) provides two ways of access: automatic and optional. Under the former one, contentious cases may be submitted to the ACtHPR unconditionally by five entities: the ACmHPR, a state party which has lodged a complaint to the ACmHPR, a state party against which the complaint has been lodged at the ACmHPR, a state party whose citizen is a victim of human rights violation and African intergovernmental organizations ${ }^{4}$. The two remaining entities, however - the non-governmental organizations (NGOs) with observer status before the ACmHPR and individuals - have direct access to the ACtHPR granted only if a state party has made a declaration (Optional declaration) to this effect under Article 34(6) of the Protocol ${ }^{5}$.

Back in the formative years of the ACtHPR it was anticipated that most cases reaching its docket would start as communications to the $\mathrm{ACmHPR}^{6}$ but it did not turn out to be so. At the time of writing (February 2017) the ACtHPR finalized 33 cases and seized upon 95 other litigations in contentious matters. Notably, in all but three cases the NGOs and individuals (and not the ACmHPR, states or

under the European Convention for the Protection of Human Rights and Fundamental Freedoms of 1950 (European Convention) and the Inter-American Court of Human Rights (IACtHR) created by the American Convention on Human Rights of 1969 (American Convention).

2 Article 2 of the Protocol to the African Charter on Human and Peoples' Rights on the Establishment of the African Court on Human and Peoples' Rights, 1998, OAU Doc. OAU/LEG/EXP/ AFCHPR/PROT (III).

3 Article 27 of the Protocol; see eg. ACtHPR, Mtikila v. Tanzania, 011/2011, ruling on reparations, 30 June 2014.

4 Article 5(1) of the Protocol.

5 Article 5(3) of the Protocol.

6 F. Viljoen, A Human Rights Court for Africa, and Africans, The Brooklyn Journal of International Law 2004/30(1), p. 23 
intergovernmental organizations) sought judicial protection in the ACtHPR. In ten out of 32 finalized cases (approx. 30 per cent) the Court decided individual applications inadmissible as respondent states had not deposited Optional declarations. The ACmHPR acted as the applicant only thrice which makes the Optional declaration a principal basis of the ACtHPR jurisdiction, even though by February 2017 only eight Optional declarations have been received by the AU Commission ${ }^{7}$. The fact used to be presented as a particularly deplorable limitation of the positive impact the ACtHPR could have upon the situation of individuals ${ }^{8}$. While the opting-in formula may encourage undecided states to accept the Protocol without fear of being faced with constant influx of individual complaints (the fate of Tanzania struggling with nearly 80 cases pending before the ACtHPR may seem rather ominous for many African states), it is doubtful if this offset pays-off from the perspective of the effective human rights protection. Notably, the lack of direct individual access to the ACtHPR forms a buffer zone between the judicial institution and the victims of human rights violations thus decreasing the number of complaints under scrutiny and, in turn, weakening level of protection offered.

Against this background it must be noted that the fundamental principle regarding the acceptance of jurisdiction of every international court is that of consent, a principle that itself is derived from the state sovereignty. Considering the consent as a resultant of a particular political calculation exercised by a state, it appears consequently that the ACtHPR is not equipped with any instruments to induce a growth in the number of the deposited Optional declarations. Nonetheless the article contends otherwise, advancing two central arguments. Firstly, the Optional declaration formula is presented as a built-in tool practically enabling the ACtHPR responsiveness to political interest of the African states unwilling to accept its jurisdiction because - as it had been argued - some of the rulings 'could throw the domestic human rights regime into disarray'. It means in particular that the ACtHPR may employ its jurisprudence instrumentally to encourage submissions of Optional declarations by hesitant states. Secondly, it is claimed that the policy, if implemented, would: correspond to the underlying features of

Benin, Burkina Faso, Côte d'Ivoire, Ghana, Malawi, Mali, Rwanda and Tanzania. However, by the letter dated 1 March 2016, Rwanda notified the ACtHPR of the deposition of an instrument of withdrawal of its declaration made under Article 34(6) of the Protocol.

8 R.W. Eno, The jurisdiction of the African Court on Human and Peoples' Rights, African Human Rights Law Journal 2002/2(2), p. 231.

9 A. Stemmet, A Future African Court for Human and Peoples'Rights and Domestic Human Rights Norms, South African Yearbook of International Law 1998/23, p. 236. 
the international society, reflect both the theory and practice of the international relations, not undermine the judicial independence and remain perfectly in line with the law of treaty interpretation.

The following parts of the paper are organised as follows. The subsequent section explains how the jurisprudence of the ACtHPR may either encourage the undecided states or deter them from making Optional declarations. It is suggested that the so-called balanced approach to the interpretation of the human rights treaties exercised deliberately by the judges may stimulate the rise in the making of Optional declarations in Africa. Ostensibly the recommendation may appear as a definitely odd and perverted suggestion to replace the desired pro homine commitment of the African judges by introducing a judicial tactic with potentially adverse consequences for the international rule of law. However the following parts of the paper prove to the contrary. The third section shows how the reality of the international society is reflected in some theoretical behavioural patterns accentuating states' intrinsic tendency and ability to exert authority over international tribunals. Then, in the fourth part, the Optional declaration system under the Protocol is presented as constituting a standard mechanism of control used by the states to secure the ACtHPR's responsiveness to their interest.

Against the backdrop of the presented theory and practice, the next two parts advance the normative approach to the problem. The discussed issue of 'judicial responsiveness' to political expectations of states is presented as reconcilable with both the principle of judicial impartiality and independence (fifth section) as well as the international law on treaty interpretation (sixth section).

Finally, the conclusive remarks summarise the key points of the analysis arguing that the constrained or balanced jurisprudence advanced by the ACtHPR at the relatively early stage of its existence would constitute a lawful and desirable tool to increase the scope of the Court's personal jurisdiction.

\section{The Relation between the jurisprudence of the ACTHPR and the scope of its personal jurisdiction}

Recent initiatives from Arusha show growing determination to raise public awareness about the role of the ACtHPR in individual cases as well as to enter into interaction with the African states on making the Optional declarations ${ }^{10}$.

10 See eg. Activity Report of the African Court for the Year 2013, EX.CL/825(XXIV). 
Yet, these efforts cannot veil an ominous fact that at October 2016 Benin has deposited its Optional declaration as the only state since $2013^{11}$.

Against the background one may argue that the initiatives to amplify the number of Optional declaration should be accompanied by something more persuasive. Namely by striking a fair balance in the Court's jurisprudence between the natural tendency to interpret human rights obligations of the states progressively and the relevant policy considerations echoing their more balanced or restrained approach in this respect. In particular there possibly exists an inherent relationship between the progressive, creative or evolutionary jurisprudence on the one hand ${ }^{12}$ and challenging the ACtHPR legitimacy advanced by the African states which refrain from depositing Optional declarations on the other.

It is trite that provisions of human rights treaties are more than often nebulous and ambiguous, especially with respect to economic, social, and cultural rights. Consequently in practice the precise meaning of established standards and corresponding states' obligations must be unfolded by judicial or quasi-judicial bodies interpreting relevant treaty stipulations pursuant to a meta-legal norm of art. 31 of the Vienna Convention on the Law of Treaties of 1969 (VCLT) ${ }^{13}$. However the problem only gets its momentum here as the general rule of treaty interpretation contained in Article 31(1) merges three different principles of interpretation (namely: textuality, ordinary meaning, teleological principle of 'object and purpose') into a single rule ${ }^{14}$. While the provision seems to presuppose adoption of the so called 'crucible approach' leading to a balanced and uniform combination of the various interpretive elements of Articles 31(1) into a single operation ${ }^{15}$, it is not always the case when the VCLT is applied in practice. In particular there are various schools of interpretation characterized by an adopted inclination of a judge to accentuate particular elements envisaged by art. 31(1) VCLT. Opposite poles of the more nuanced spectrum ${ }^{16}$ are marked by the two distinct approaches.

$11 \mathrm{https} / / / \mathrm{www} . a u . i n t / w e b /$ sites/default/files/treaties/7778 sl-protocol_to_the_african_charter_on_ human_and_peoplesrights_on_the_establishment_of_an_african_court_on_human_and_peoples_rights_17.pdf; accessed on 05.03.2017 r.

12 E. Bjorge, The Evolutionary Interpretation of Treaties, OUP 2014.

13 UNTS, 1155, p. 331.

14 M. Fitzmaurice, Interpretation of Human Rights Treaties, in: D. Shelton (ed.), The Oxford Handbook of International Human Rights Law, OUP 2013, para 3.2.

15 R. Gardiner, Treaty Interpretation, OUP 2015, p. 10.

16 F.G. Jacobs, Varieties of Approach to Treaty Interpretation: with Special Reference to the Draft Convention on the Law of Treaties Before the Vienna Diplomatic Conference, International \& Comparative Law Quarterly 1969/18(2), p. 318. 
The so-called textual approach represents content-based interpretation as it is focused primarily on the ordinary meaning of the words used in the text ${ }^{17}$. Definitely, the sole literal meaning of the terms used in human rights treaties may not bring a judge very far, hence the literal interpretation usually serves as a starting but, at the same time, determining point for the 'interpretative exercise' engaging other techniques ${ }^{18}$. On the other hand, the teleological or progressive approach brings out the object and the purpose of the treaty thus expanding the scope of the human rights protection agreed by the state-parties far beyond their original intentions expressed in the text ${ }^{19}$.

The difference between the two approaches may be observed in various aspects of the judicial reasoning. In particular, the progressive stance (in comparison to the textual approach) allows to extend the applicability of a given provision $^{20}$, to broaden the scope of states' positive obligations ${ }^{21}$, to advance extra-legal motives ${ }^{22}$, to distil obligations of result (as opposed to obligations of

17 P. Brest, The Misconceived Quest for the Original Understanding, Boston University Law Review 1980/60, p. 205.

18 O.J. Settem, Applications of the 'Fair Hearing' Norm in ECHR Article 6(1) to Civil Proceedings: With Special Emphasis on the Balance Between Procedural Safeguards and Efficiency, Springer 2015, p. 17.

19 W. Sandholtz, Expanding rights: norm innovation in the European and Inter-American court, in: A. Brysk, M. Stohl (eds.), Expanding Human Rights: 21 st Century Norms and Governance, Edward Elgar Publishing 2017, pp. 160-176.

20 Eg. on 13 December 2016, the Grand Chamber of ECtHR delivered a judgment notably increasing the group of beneficiaries under Article 3 of the European Convention protected against removal or deportation due to medical reasons, Paposhviliv. Belgium, 41738/10. The ECtHR adopted the progressive approach rejecting argument that 'a general obligation to provide social welfare assistance could not be inferred from Article 3 even in the name of human dignity', para 150.

21 Eg. the ACmHPR confirmed that the protection afforded by Article 7 of the Banjul Charter is not limited to the protection of the rights of arrested and detained persons. It also encompasses the right of every individual to access the relevant judicial bodies competent to have their causes heard and be granted adequate relief, Zimbabwe Human Rights NGO Forum v. Zimbabwe, 245/02, para 213 .

22 Indubitably, such a progressive stance is influenced by value-based commitment (or a valuebased bias) of judges. For example, in the Campbell case there were strong legal reasons to declare the claim inadmissible. The Judges decided otherwise, however, apparently driven by their strong commitment to the idea of human rights protection, Southern African Development Community Tribunal, Mike Campbell (Pvt) Ltd. And Others v. Zimbabwe, 2/2007, judgment, 28 November 2008. Similar instances of judicial activism and attempts to rewrite a constitutive legal instrument may be also found elsewhere. For example, the ECtHR granted locus standi to the applicant against the letter of the treaty with judges clearly admitting no support for such decision found in the text of the European Convention but, to the contrary, advancing equitable 
conduct) from the economic social and cultural rights and to recognize human rights merely implied in the existing provisions ${ }^{23}$ or, last but not least, to expand the competences of an organ far beyond the stipulations contained in a relevant treaty ${ }^{24}$. Such a progressive practise has philosophical, legal and purely practical implications. Firstly, it evokes the classical dispute between Hart and Fuller on application of moral positions embedded in the substantive law ${ }^{25}$. Secondly, it revolves around a question on whether and, if so, how progressive reading of a treaty is to be reconciled with the international norms of treaty interpretation. Finally, it forms an important factor within political calculations of states on whether to accept jurisdiction of an international tribunal or not and how to approach its jurisprudence.

resort to just solutions in the circumstances of the case which 'were exceptional', Center for Legal Resources on behalf of Valentin Câmpeanu v. Romania, 47848/08, judgment, 17 July 2014.

23 Eg. the ACmHPR confirmed in 2009 the right of indigenous groups to participate at all levels of decision-making in matters which may affect them, although the right is not provided in the Banjul Charter, Centre for Minority Rights Development (Kenya) and Minority Rights Group (on behalf of Endorois Welfare Council) v. Kenya, 276/03, paras 227-228.

24 Article 58(1) of the Banjul Charter stipulates that the ACmHPR can consider an individual communication only if it reveals a series of serious and massive violations of human and peoples' rights, and only after the Assembly of Heads of state and Government has requested to do so. However, in practice, the ACmHPR considers every communication even if it refers to only a single violation of the Banjul Charter. Such progressive reading was in the past contested by States and examined by the doctrine, see: W. Benedek, The African Charter and Commission on Human and Peoples' Rights: How to Make it More Effective, Netherlands Quarterly of Human Rights, 1993/11, p. 31; R. Murray, Decisions by the African Commission on Individual Communications Under the African Charter on Human and Peoples' Rights, International \& Comparative Law Quarterly 1997/46, pp. 412-413.

25 The famous Hart-Fuller debate was an exchange of views published in the Harvard Law Review in 1958 and nearly sixty years after still epitomizes a division between the positivist and natural philosophy of law. Hart tried to prove that there is no necessary relationship between a legal system and ideas of justice or morality. Fuller rejected such position maintaining that 'morality of order' is indispensable to the creation of all law. The character of the controversy is absolutely fundamental for the jurisprudence and manifests in countless forms including behavioural implications for the problem discussed here. For example, an international judge accepting the Fuller's position and adhering to moral (or metalegal) evaluation of the treaty norm will be more inclined to the value-based bias while deciding cases; H.L.A. Hart, Positivism and the Separation of Law and Morals, Harvard Law Review 1958/71(4), pp. 593-629; L.L. Fuller, Positivism and Fidelity to Law: A Reply to Professor Hart, Harvard Law Review 1958/71(4), pp. 630-672; G.I. Hernández, Impartiality and Bias at the International Court of Justice, Cambridge Journal of International and Comparative Law 2012/1(3), pp. 188 et seq. 
It seems evident that while progressive interpretation of human rights treaties is usually appraised by individuals and human rights activists, it may also, potentially, provoke a fierce backlash from infuriated states refusing to comply with the decisions of tribunals or deciding to withdraw from their jurisdiction with detrimental effect to the situation of individuals ${ }^{26}$. In particular, the progressive approach to the treaty interpretation displayed by judges within their decision making process, for example through the preference given to the moral reading of the Banjul Charter over the more textual approach, may be perceived by states as a factor potentially inhibiting their interests and thus increasing reluctance to accept the blanket jurisdiction of the ACtHPR in individual cases.

On the other hand, the direct individual access to the ACtHPR might possibly be expanded if the states regarded the judges in Arusha as the even-tempered guardians of the Banjul Charter accentuating both the textualism in its hermeneutics as well as the contextualization of the obligations of those states against the African cultural and political background. In particular, the adoption of the balanced approach should possibly reduce the risk of states being upset with the legitimacy of the progressive approach. States are concerned because the latter is perceived as: (a) bypassing the sovereign consent on the agreed text of the treaty; (b) amounting to usurpation of a quasi-legislative position by elected judges who question a decision made by democratically elected organs) and (c) impairing certainty and predictability of the law ${ }^{27}$.

The very idea of the balanced approach rests on four main premises. Firstly, the ACtHPR, while applying Article 31(1) VCLT should refrain from advancing solely "the object and purpose" principle and adopt a more equipoise and uniform combination of the various interpretive elements of the norm. Secondly, various interpretation techniques (as the margin of appreciation and the concept of the continental consensus) may serve as tools enabling the Court to accommodate the states' position while decoding the meaning of the Banjul Charter. Thirdly, the comparative method applied for the interpretation of the Banjul Charter must not go as far as to mechanically transplant attitudes developed in different social contexts by the other regional human rights courts. Finally, the promotion of

26 It is claimed for example, that the IACtHR simultaneously challenged the core policies of several states at once thus facing their 'voicing' of dissatisfaction and withdrawal from the system, T. Ginsburg, Political Constraints on International Courts, in: C.P.R. Romano, K.J. Alter, Y. Shany (eds.), The Oxford Handbook of International Adjudication, OUP 2013, pp. 501 et seq.

27 K. Dzehtsiarou, European Concensus and the Evolutive Interpetation of the European Convention on Human Rights, German Law Journal 2011/12(10), p.1734. 
amicable settlement of disputes under the auspices of the Court ${ }^{28}$ may strengthen its position as a conciliatory body, more in line with the states' attitude canvassing the African system where sensitive issues of human rights violations could only be dealt with in a non-confrontational atmosphere ${ }^{29}$.

While the vision of the court of justice instrumentally shaping its jurisprudence to achieve some political aims may raise legitimate concerns as undermining audaciously the international rule of law, the following section places the argument in a broader theoretical context of international relations. It suggests in particular that the structure of the international society directly necessitates this kind of interaction between the states and the international judiciary.

\section{Arbiters, trustees or agents? Provocative realism and the role of international tribunals}

Founding fathers of international law were astute observers of how nations act towards one another in the context of dispute resolutions. De Vattel, who developed abstract rules of the law of nations covering actual practice and customs $^{30}$, articulated the view that a careful distinction must be made between essential and less important rights of states with different lines of conduct to be pursued. He argued, in particular, that there was a duty to negotiate and to seek arbitral decisions only "where interests that are not essential, or are of small consequences, are involved' 31 .

A few hundred years later, perfectly in the same vein, Morgenthau supported realism while forging his international-relations theory. He stated inter alia that there exist some limits for international resolution of disagreements based on the division between 'disputes' and 'tensions'. The distinction is necessarily not a clear-cut one as being based on a very subtle and frequently silenced factor of politicization canvassing a dispute. It is claimed that while in theory nearly all 'disputes' and 'tensions' between States may be expressed in purely legal terms,

28 Article 57(1) of the Banjul Charter.

29 M. Evans, T. Ige, R. Murray, The Reporting Mechanism of the African Charter on Human and Peoples'Rights, in: M. Evans, R. Murray (eds.), The African Charter on Human and Peoples' Rights. The System in Practice, 1986-2000, CUP 2002, p. 36.

30 P.P. Remec, The Position of the Individual in International Law according to Grotius and Vattel, Springer Science \& Business Media 2012, pp. 187-188.

31 E. de Vattel, Le Droit des gens, ou Principes de la loinaturelle: appliqués à la conduite et aux affaires des nations et des souverains, 1758, Book II, Chapter xviii, para 332. 
the latter designation refers to particularly complicated cases involving a discrepancy between the legal situation on the one hand and the actual power relation (or essential political interest of the states involved) on the other. As it would be naive to believe that conflicts invested with extreme emotional or political intensity would be effectively resolved through international adjudication, 'tensions' and 'disputes' are not equally susceptible to international adjudication ${ }^{32}$. In particular it is claimed that formal dispute settlement bodies could not adequately deal with such 'tensions"33.

Against this background, states that face proliferation of international tribunals at present must act in such a way as to maximize their political interest ${ }^{34}$. This behavioural approach explains the fact that sovereigns try to advance their cause and maintain control over international tribunals either limiting their jurisdiction by excluding 'tensions' from the competence of the courts or rejecting $i^{35}$. Limiting restrictions may take various forms with jurisdictional optional clauses or optional protocols amongst them.

32 H.J. Morgenthau, Positivism, Functionalism, and International Law, American Journal of International Law 1940/34(2), pp. 275-276.

33 M.C. Williams, Realism Reconsidered: The Legacy of Hans Morgenthau in International Relations, OUP 2007, p. 97. There are numerous examples supporting the view. For example, although Germany had become a party to the Treaty of Versailles in 1919, later on the State decided to oppose its stipulations due to the anger over perceived injustice. It was argued, from the German point of view, that such violations of the Treaty were not justiciable and as such could not be efficiently dealt with by international tribunals, U. Greenberg, The Weimar Century: German Emigres and the Ideological Foundations of the Cold War, PUP 2015, pp. 217-218. Similarly, when on 12 July 2016 the Permanent Court of Arbitration had issued its Award in the Republic of the Philippines v. People's Republic of China deciding on a highly politicized issue of maritime and territorial claims, the Respondent rejected the ruling, see: Press Statement of the Chinese President Xi Jinping, available at http://english.cri.cn/12394/2016/07/12/4161s933936.htm, accessed on 16 February 2017. Even before the publication of the Award, the Chinese Ministry of Foreign Affairs had made it clear that all maritime disputes should be addressed through negotiations and agreements between the parties concerned, 18 April 2016 Joint Communique of the Foreign Ministers of the Russian Federation, the Republic of India, and the People's Republic of China, para 21. Recently, the Russian Constitutional Court found on 17 January 2017 that Russia was not bound to enforce the ECtHR decision of 15 December 2014 on the award of 1,9 billion EUR (sic!) as pecuniary compensation to the defunct Yukos oil company ex-shareholders. The Russian Court argued oddly that that the principle of state sovereignty and non-interference in internal matters of a state constitutes jus cogens and therefore allows for derogation from the pacta sunt servanda principle under art. 53 VCLT; http://doc.ksrf.ru/ decision/KSRFDecision258613.pdf, accessed on 17 February 2017.

34 E. Goldsmith, J. Posner, The Limits of International Law, OUP 2005, p. 3.

35 E. Posner, J.C. Yoo, Judicial Independence in International Tribunals, California Law Review 2005/93(1), pp. 72-73. 
Unfurling the realistic approach, Posner and Yoo, in their famous and controversial article published in $2005^{36}$, argued that international tribunals may be useful in dispute resolution mainly as far as they provide information on the facts and rules of conduct. On the other hand, nevertheless, to be exploited by states they must act consistently with the interests of sovereigns that had created them. In other words: to be effective, which is measurable inter alia by the scope of jurisdiction, international courts cannot be independent with judges vulnerable to the influence of states and thus not impartial in a strict sense. This radical view epitomizes the so-called Principal-Agent Theory - one out of few modern hypotheses seeking to explain why and under what circumstances sovereign states delegate competences to international judges. The theory underlines vulnerability and dependence of tribunals to states which are reluctant to entrust their essential interests to a dice-throw-like, purely legal, decision-making process before a strictly impartial tribunal.

While undeniably hyper-realistic (and cynical), the presented supposition may be perceived as contradicting an observable fact that impartiality and independence of international judges is usually guaranteed in treaties constituting international tribunals. Not to mention that international tribunals typically do act without any obvious symptoms of states tinkering with the judicial independence. Unsurprisingly then, other theoretical models have mushroomed trying to reflect international practice more precisely in the scope of behavioural patterns. Thus, the Trustee Theory presents international judges as trustees bringing their own legitimacy and authority, and empowered to undermine interests of sovereign states $^{37}$. The Altered Politics Framework ${ }^{38}$ goes even further in accentuating judicial independence of international courts stressing their competence to extend their powers beyond treaty-based framework ${ }^{39}$. As a matter of fact, the Framework forms an empiric approach measuring the effectiveness of international courts by their capacity to influence states and international organizations in order to advance particular objectives already inscribed in the law ${ }^{40}$.

36 Ibidem.

37 A.S. Sweet, T.L. Brunell, Trustee Courts and the Judicialization of International Regimes: The Politics of Majoritarian Activism in the ECHR, the EU, and the WTO, Journal of Law and Courts 2013, p. 61.

38 K.J. Alter, The New Terrain of International Law, PUP 2014, pp. 62 et seq.

39 J. Gathii, Mission Creep or a Search for Relevance: The East African Court of Justice's Human Rights Strategy, Duke Journal of Comparative \& International Law 2013/24, pp. 283 et seq.

40 G.I. Hernández, The Judicialization of International Law: Reflections on the Empirical Turn, The European Journal of International Law 2014/25(3), pp. 921-922. 
While such theories undeniably contribute to ongoing discussion on the role of the international adjudication, they also construct clearly one-dimensional models through advancing only selected aspects of the complex reality. Then, a more balanced model has been required with the gap being filled by Helfer and Slaughter forwarding the middle path of the Constrained Independence Theory ${ }^{41}$. They submit that states decide to establish formally independent international tribunals to augment the credibility of their commitments. However, at the same time, states rely on structural, political and discursive mechanisms to ensure that independent judges are operating within a set of legal limits and political constraints thus making sovereigns' essential interests properly secured.

Practically speaking, sovereigns' actions are employed as two-layered shield, protecting states against both: (a) judges' detachment from political reality canvassed with sovereign interest as well as against (b) illegal influences upon decision-making process by other states. To achieve the first aim, sovereigns utilize legal and political devices ensuring responsiveness of the court to their political will. The second one is secured as states set up an institutional framework delineating parameters of judicial independence and autonomy in decision making process. In this way they try to guarantee the tribunal is not prejudiced against their own interest.

\section{Optional declarations as a mechanism for states' regulation of the ACTHPR}

Turning to the ACtHR against the background presented above, a particular political context of its establishment must not be ignored while analysing its position towards the African states. Neither the Charter of the Organisation of African Unity ${ }^{42}$ nor the Banjul Charter provided for the establishment of the judicial institution redressing violations of human rights. Various explanations were provided with frequent references to African tradition underlining consensus and reconciliation as more valued than juridical settlements of disputes ${ }^{43}$. Other analyses, however, stressed self-interest and preoccupation of the African

${ }^{41}$ L.R. Helfer, A.-M. Slaughter, Why States Create International Tribunals: A Response to Professors Posner and Yoo, California Law Review 2005/93(3), p. 899.

42 UNTS, 479, p. 39.

43 N.J. Udombana, Toward the African Court on Human and Peoples'Rights: Better Late Than Never, Yale Human Rights and Development Journal 2000/3(1), p. 74. 
states with the principle of sovereignty and non-interference ${ }^{44}$. Only in the early 1990s the process leading to the strengthening of the regional system of human rights protection was renewed under the pressure exerted by external actors ${ }^{45}$ and the disappointment with the human rights protection system based upon the $\mathrm{ACmHPR}^{46}$. Yet, when the Protocol was finally accepted, the decision to establish the ACtHPR was driven by one underlying motive: to safeguard the interests of states even at the expense of a more effective protection of human rights. Such a restraint was understandable considering that in the instances in which the given tribunal decides in disputes with individuals directly involved, it is more inclined to a teleological and progressive interpretation than in the cases in which only governments are parties ${ }^{47}$. Such practice, in turn, encourages other private actors to use or to support the court, especially if states have no final say on which cases may be brought before it. In such circumstances, international tribunals are inclined to apply more and more progressive ways of treaty interpretation, gaining momentum if they obtain support in this respect from, for example, media and non-governmental organizations ${ }^{48}$.

Naturally, the problem of allowing individuals to submit cases to ACtHPR was one of the most hotly debated issues during the drafting of the Protocol ${ }^{49}$. Gambia bluntly summarized the position of the majority of negotiating states proclaiming that the optional access for individuals and NGOs 'safeguards the integrity of the State and avoids vexatious and embarrassing actions being brought directly to the Court ${ }^{50}$. Unsurprisingly then, having such a particular political environment which nestled the establishment of the ACtHPR, the legal parameters of its competences were constructed within Article 34(6) of the Protocol limiting

${ }_{44}$ F. Viljoen, A Human Rights..., p. 6.

45 G. Bekker, The African Court on Human and Peoples' Rights: Safeguarding the Interests of African States, Journal of African Law 2007/51(1), p. 159.

46 M. Mutua, The African Human Rights Court: A Two-Legged Stool?, Human Rights Quarterly 1999/21, p. 352.

47 L.R. Helfer, A.-M. Slaughter, Why States..., p. 567.

48 J. Pauwelyn, M. Elsig, The Politics of Treaty Interpretation: Variations and Explanations across International Tribunals, in: J.L. Dunoff, M.A. Pollack (eds.), Interdisciplinary Perspectives on International Law and International Relations Variations and Explanations across International Tribunals, CUP 2012, pp. 465-466.

49 I.A. Badawi, Draft Protocol to the African Charter on Human and People's Rights on the Establishment of an African Court on Human and Peoples'Rights - Introductory Note, African Journal of International and Comparative Law 1997/9, p. 947.

50 R. Wright, Finding an Impetus for Institutional Change at the African Court on Human and Peoples'Rights, Berkeley Journal of International Law 2006/24(2), pp. 478-479. 
not only its jurisdiction but also its practical role in human rights enforcement on the continent.

The legality of this provision has been challenged at least twice. In the Femi Falana versus $A U$ case $^{51}$, the applicant argued before the ACtHPR that Article 34(6) of the Protocol was inconsistent with numerous provisions of the Banjul Charter. In a more recent attempt, the EACJ in Democratic Party versus Secretary General of the East African Community and Others case ${ }^{52}$ was asked to declare that the fact of signing the Protocol also creates an obligation under EACT on member states to make Optional declaration. In both cases, the applicants' contentions were inevitably doomed to collapse either due to the lack of jurisdiction over the respondent (Femi Falana case) or the finding that failure to deposit or delay in depositing an Optional declaration had violated neither the Banjul Charter, the Protocol nor EACT (Democratic Party case).

While the Optional declaration is sometimes dubbed "cynical' ${ }^{53}$ by human rights lawyers who are inclined to approach international relations anthropomorphically, from the perspective of international law it is a standard normative mechanism limiting jurisdiction of the ACtHPR and excluding unwilling states from its jurisdiction upon individual complaints. Besides, in practice, it also acts as instrument of political constraint stimulating the ACtHPR responsiveness to political interest of the African states.

Understandably, such a proposal of the self-restraining court motivated by the political circumstances may be attacked from the legalist standpoint. Especially since all international disputes are, as Lauterpacht once famously claimed, disputes of a legal character. It means that as long as the rule of law is recognized they can be addressed by the application of legal rules ${ }^{54}$ and legal rules only. For this reason, there is, apparently, no room for policy considerations. In particular, the balanced approach applied deliberately by the ACtHPR to increase the Optional declarations ratio seems to be falling short of the judicial independence and impartiality requirements and running afoul of the VCLT principles of treaty interpretation. However, under closer scrutiny presented in the next two sections, the recommended practice seems reconcilable with both sets of legal standards.

ACtHPR, 001/2011, judgment, 26 June 2012.

52 East African Court of Justice, 2/2012, judgment, 19 November 2013.

53 J. Harrington, The African Court on Human and Peoples' Rights, in: M. Evans, R. Murray, The African..., p. 319.

54 H. Lauterpacht, M. Koskenniemi, The Function of Law in the International Community, OUP 2011, p. 166. 


\section{Judicial impartiality and independence}

At present, judicial impartiality and independence of domestic judges are perceived as instrumental in the protection of all individual rights ${ }^{55}$ and hence constitute an indispensable foundation of the specific human right to a fair trial (and thus access to justice) before domestic courts and tribunals. Judicial impartiality - this particular 'function of personality and of an elevated attitude of mind' ${ }^{56}$ - means deciding matters before judiciary on the basis of facts and in accordance with the law, without any bias, restrictions, improper influences, inducements, pressures, threats or interferences, direct or indirect, from any quarter or for any reason. Judicial independence, in turn, is the duty of all governmental and other institutions to refrain from any inappropriate or unwarranted interference with the judicial process or revision of judicial decisions impairing judicial impartiality. On the general level, both impartiality and independence must be ensured through public respect for the courts and the judges' self-perception as impartial and independent ${ }^{57}$.

The international adjudication apparently serves the same purpose as the domestic one: to resolve disputes. Not surprisingly then, one may be inclined to elevate the aforementioned perception of judicial impartiality and independence to the international level. In this way the ICJ has found that it had to act only on the basis of the law independently of all outside influence or interventions whatsoever in the exercise of the judicial function entrusted to it by the Charter and its Statute alone. A court functioning as a court of law can act in no other way ${ }^{58}$. It is evident then that impartiality and independence form an ethical value central to the international rule of law ${ }^{59}$. At the same time it must be noted that the nature of judicial impartiality and independence is clearly functional considering them being shaped not for their own sake but in order to protect the process of rendering justice. It means that their content is not static and hence the required degree of impartiality and independence may vary from court to court. In particular, it is to

5 T. Meron, Judicial Independence and Impartiality in International Criminal Tribunals, American Journal of International Law 2005/99(2), p. 359.

56 H. Lauterpacht, M. Koskenniemi, The Function..., p. 228.

57 T. Meron, Judicial..., p. 360.

58 ICJ, Legal Consequences for States of the Continued Presence of South Africa in Namibia (South West Africa) notwithstanding Security Council Resolution 276 (1970), advisory opinion, 21 June 1971, ICJ Reports 1971, p. 11.

59 F. Mégret, What Is International Impartiality?, in: V. Popovski, International Rule of Law and Professional Ethics, Ashgate 2014, p. 101. 
be determined against the background of the actual threats undermining judicial function with clear differences between domestic and international tribunals.

What is more, the empirical researches made by Posner and de Figueiredo ${ }^{60}$ confirm an intuitive expectation that the judicial decision-making process is inseparably intertwined with complicated subjective motives originating definitely outside the scope of the normative framework applicable in a given case. The presence of such motives may potentially constitute a serious threat to the international judicial impartiality and independence. However the next section proves that a deliberate decision of a judge to adjudicate according to the balanced approach only to induce submission of the Optional declarations by the undecided states does not amount to an extra-legal factor in the sense mentioned above. To the contrary, it forms an element of reasoning deeply embedded in the VCLT principles of treaty interpretation.

\section{The interpretation of treaties}

Interpretation of treaties by international tribunals is aimed at giving meaning to legal texts against the background of decided cases. General rules of treaty interpretation are contained in Articles 31 and 32 of the VCLT but it is widely accepted that they reflect pre-existing customary international law ${ }^{61}$. Treaty hermeneutics presented by the VCLT is based upon two principles. The first one being that treaties must be interpreted in good faith, in accordance with the ordinary meaning of the terms or text of the treaty, in their context, and in light of their object and purpose. The second one furthermore states that recourse

60 E. Posner, M.F.P. de Figueiredo, Is the International Court of Justice Biased?, Journal of Legal Studies, 2005/34, p. 599. Tracing such a bias is not an easy task, however, in some circumstances it is nearly impossible to exclude the factor. For example, in October 2016 the ICJ ruled on the preliminary objections in the cases brought by Marshall Islands on the obligation to pursue nuclear disarmament. The Court upheld the preliminary objection of the United Kingdom of Great Britain and Northern Ireland, by the President's casting vote based on the absence of a dispute between the parties. As much as six (out of the eight) judges who found the dispute lacking are nationals of nuclear-weapon states. The remaining judges in the minority are all nationals of states that do not possess nuclear weapons; ICJ, Obligations Concerning Negotiations Relating to Cessation of the Nuclear Arms Race and to Nuclear Disarmament (Marshall Islands v. United Kingdom), Preliminary Objections, judgment, 5 October 2016, ICJ Reports 2016.

${ }^{61}$ ICJ, Arbitral Award of 31 July 1989 (Guinea Bissau versus Senegal), judgment, 12 November 1991, ICJ Reports 1991, p. 70; see also O. Dörr, Observance, Application and Interpretation of Treaties, in: O. Dörr, K. Schmalenbach (eds.), Vienna Convention on the Law of Treaties, Springer 2012, p. 523. 
may be had to supplementary means of interpretation, including the preparatory work of the treaty and the circumstances of its conclusion, in order to confirm the meaning resulting from the application of the first principle or to determine the meaning when the interpretation according to the first principle either leaves the meaning ambiguous or obscure, or leads to a result which is manifestly absurd or unreasonable. The presented norms give considerable flexibility to the interpreting body ${ }^{62}$, in particular in the context of human rights treaties operating with general clauses and nebulous terms.

Under such circumstances, it appears in practice that what is explicitly presented by any given international court as treaty interpretation under customary law or the VCLT, is in fact nothing more than the ex post validation of the final effect of reasoning reached on other implied basis. Pauwelyn and Elsig accurately point that while interpreting treaty an international tribunal must make some interpretational choices as to, for example: the dominant hermeneutic (text, party intent, or underlying objective), timing (original or evolutionary interpretation) and activism (work-to rule approach or gap-filling approach $)^{63}$. Thus, for example, the ECtHR prefers underlying objective approach over party intent or textual approach and thus favours morals and equitable solutions ${ }^{64}$. Similarly, the IACtHR uses instruments 'foreign' to the Inter-American system to expand the content of rights in the American Convention ${ }^{65}$ promoting the gap-filling approach over work-to rule approach. Pauwelyn and Elsig further suggest ${ }^{66}$ that such interpretation choices are the result of two variables. The first is interpretation space available under provisions of given treaty. The second, particularly important in the discussed context, refers to intrinsic motivations of judges who operate within that space. Such motivations may include their legal tradition or professional background as well as their inclination to boost up the compliance rate of the tribunal through judgments not generating the opposition of states or to expand the merit scope of human rights protection (it has been already maintained that compulsory jurisdiction of a tribunal over disputes with private

62 M.E. Villiger, Commentary on the 1969 Vienna Convention on the Law of Treaties, Martinus Nijhoff Publishers 2009, p. 440.

63 J. Pauwelyn, M. Elsig, The Politics..., pp. 449 et seq.

${ }^{64}$ G. Letsas, Strasbourg's Interpretive Ethic: Lessons for the International Lawyer, European Journal of International Law, 2010/21(3), p. 509.

${ }^{65}$ L. Lixinski, Treaty Interpretation by the Inter-American Court of Human Rights: Expansionism at the Service of the Unity of International Law, European Journal of International Law 2010/21(3), p. 585

66 J. Pauwelyn, M. Elsig, The Politics..., p. 459. 
individual access induce judges to be more active and to expand the reach and scope of the obligations of states ${ }^{67}$.

Making such interpretational choices appears then as an imminent and indispensable element of every judicial reasoning, in consequence practically validating the view that administering justice in a state of perfect intellectual and emotional detachment, not influenced by judge's cultural or value-based background, is nothing more than an idealistic fiction. While such a conclusion apparently undermines the foundations of international adjudication by heralding domination of 'the rule of calculation', 'the rule of law' is nonetheless maintained. That is so because unspoken political or moral choices are not only difficult to detect but are, above all, made usually within the treaty interpretation process, although in its particular penumbral zone exploiting inherent imprecision of applicable norms of treaty interpretation. Accordingly, it means that judicial interpretation of treaties striking a fair balance between the natural tendency to interpret human rights obligations of states progressively and the relevant policy considerations echoing their more conservative approach in this respect, violates neither norms of treaty interpretation nor judicial impartiality and independence.

Moreover, the normative background of the ACtHPR provides useful legal mechanisms to accommodate such an approach within interpretation process. Article 3 of the Protocol provides that the jurisdiction of the ACtHPR extends to all cases and disputes on the interpretation and application of the Banjul Charter, the Protocol and any other relevant human rights instrument ratified by the states concerned. Such an unprecedentedly extended scope of subject matter jurisdiction used to be presented as a source of multiple problems inter alia with divergent jurisprudence and thus possible fragmentation of the international human rights protection ${ }^{68}$. In practice, however, the ACtHPR clearly displays a holistic approach in treaty interpretation trying to 'fortify' its reasoning on the jurisprudence of other international bodies (the UN Human Rights Committee, the ECtHR, the IACtHR) ${ }^{69}$. What is more, the ACtHPR also draws inspiration from such particular concepts of treaty interpretation as margin of appreciation ${ }^{70}$.

${ }^{67}$ K.J. Alter, L.R. Helfer, Nature or Nurture? Judicial Lawmaking in the European Court of Justice and the Andean Tribunal of Justice, International Organization 2010/64, p. 567.

68 F. Viljoen, A Human Rights..., p. 47.

69 Eg. Alex Thomas v. Tanzania, 005/2013, judgment, 20 November 2015, paras 959798104 116120.

${ }^{70}$ Mtikila case op. cit. note 3, para 106.3. 
While the concept is not new ${ }^{71}$ and cannot be limited to the realm of human rights protection $^{72}$, it is still best known as a tool applied by the ECtHPR to draw the scope of the obligations of states under the European Convention. In particular, the ECtHPR used to stress that in the view of the lack of a uniform approach on given issue questioned by the contracting states and the nature of the sensitive moral and ethical issues involved, the states enjoy a wide margin of appreciation in this field. This wide margin of appreciation in principle extends both to their decision to intervene in the area and, once having intervened, to the detailed rules they lay down in order to achieve a balance between the competing public and private interests ${ }^{73}$. There are plenty of factors influencing practical application of the concept with a prominent role played by the existence of regional consensus on given issue. If such consensus is present, based on settled and long-standing principles established in the laws of the relevant states - it narrows the margin of appreciation of the state ${ }^{74}$. Therefore, margin of appreciation amounts not only to a mere technique of treaty interpretation but being parameterized by the current states practice helps the court to strike a proper balance between progressive development of human rights jurisprudence and political ability of states to accommodate such progressive development. Of particular importance is the fact that margin of appreciation, while being deeply contextualized, does not foreclose progressive reading of a constitutive treaty. In turn, it sets its pace in line with an emergence of a wider regional consensus upon given issue thus being a vehicle for the African exceptionalism inherent to the Banjul Charter.

\section{Conclusion}

The article has presented the ACtHPR as a progeny of both international society and a special context of post-colonial legacy on the African continent inclining states to advance full control over their interest. In particular, the newly independent states perceived the right to individual petition at the international level through the prism of vulnerable sovereignty and fragile domestic legal systems. Consequently the system of the Optional declarations was introduced to secure

71 Permanent Court of International Justice, S.S. Lotus (France versus Turkey), judgment, 7 September 1927, Publications of the PCIJ Series A - No. 10, p. 18-19.

72 ICJ, Conditions of Admission of a State to Membership in the United Nations (Article 4 of the Charter), advisory opinion, 28 May 1948, ICJ Reports 1948, p. 63.

73 ECtHR, S.H. and Others v. Austria, 57813/00, judgment, 3 November 2011, para 53.

74 Ibidem, para 96. 
their (allegedly threatened) sovereignty, although at the same time the scope of the personal jurisdiction of the ACtHPR was significantly limited.

While the legal parameters of the ACtHPR competences seem stable with the political climate currently unfavourable to the Protocol amendments, the Optional declaration regime constitutes a platform enabling interaction between the Court and the African states, viable to boost regional support for enhanced jurisdiction of the ACtHPR. Notably the balanced approach to the interpretation of human rights treaties, exercised consciously by the judges, may be used as a lawful tool to stimulate the rise in the making of Optional declarations in Africa. While the Protocol apparently encourages cross-fertilization of human rights standards in Africa through references to universal treaties, the ACtHPR should be especially cautious in applying some progressive interpretative mechanisms crafted in other jurisprudences, such as evolutionary nature of human rights, the presumption that rights must be practical and effective and the creative and strategic approach to remedies. In this context, it must not be overlooked that the Court is still in its formative period entering the sixteenth year after entry into force of the Protocol with a caseload comparable to the ECtHR docket in 1969. Critical opinions on its role accentuating limited individual access thus seem premature as are the advanced proposals of foreign economic incentives generating institutional changes at the ACtHPR ${ }^{75}$. Taking a more balanced approach by the judges is nothing more than a permissible judicial tactics susceptible to change in the future once the ACtHPR gets more allies and enters the compliance rate inducing all participants in the system to implement its rulings.

\section{Bibliography}

\section{Treaties}

African Charter on Human and Peoples' Rights (Banjul Charter), 27 June 1981, OAU Doc. CAB/ LEG/67/3 rev. 5 .

American Convention on Human Rights, 22 November 1969, available at: http://www.refworld. org/docid/3ae6b36510.html; accessed 25.09.2017 r.

Charter of the Organisation of African Unity, 25 May 1963, UNTS, 479.

European Convention for the Protection of Human Rights and Fundamental Freedoms, 4 November 1950, ETS 5 .

Protocol to the African Charter on Human and Peoples' Rights on the Establishment of the African Court on Human and Peoples' Rights, 10 June 1998, OAU Doc. OAU/LEG/EXP/AFCHPR/ PROT(III).

75 R. Wright, Finding..., pp. 490 et seq. 


\section{Books and articles}

Alter Karen J., The New Terrain of International Law, PUP 2014.

Alter Karen J., Helfer Laurence R., Nature or Nurture? Judicial Lawmaking in the European Court of Justice and the Andean Tribunal of Justice, International Organization 2010/64.

Badawi Ibrahim A., Draft Protocol to the African Charter on Human and People's Rights on the Establishment of an African Court on Human and Peoples' Rights - Introductory Note, African Journal of International and Comparative Law 1997/9.

Bekker Gina, The African Court on Human and Peoples'Rights: Safeguarding the Interests of African States, Journal of African Law 2007/51(1).

Benedek Wolfgang, The African Charter and Commission on Human and Peoples'Rights: How to Make it More Effective, Netherlands Quarterly of Human Rights 1993/11.

Bjorge Eirik, The Evolutionary Interpretation of Treaties, OUP 2014.

Brest Paul, The Misconceived Quest for the Original Understanding, Boston University Law Review 1980/60.

Brysk Alison, Stohl Michael (eds.), Expanding Human Rights: 21st Century Norms and Governance, Edward Elgar Publishing 2017.

Dörr Oliver, Schmalenbach Kirsten (eds.), Vienna Convention on the Law of Treaties, Springer 2012.

Dunoff Jeffrey L., Pollack Mark A. (eds.), Interdisciplinary Perspectives on International Law and International Relations Variations and Explanations across International Tribunals, CUP 2012.

Dzehtsiarou Kanstantsin, European Concensus and the Evolutive Interpetation of the European Convention on Human Rights, German Law Journal 2011/12(10).

Eno Robert W., The jurisdiction of the African Court on Human and Peoples' Rights, African Human Rights Law Journal (2002)/2(2).

Evans Malcolm, Murray Rachel (eds.), The African Charter on Human and Peoples'Rights. The System in Practice, 1986-2000, CUP 2002.

Fuller Lon L., Positivism and Fidelity to Law: A Reply to Professor Hart, Harvard Law Review 1958/71(4).

Gardiner Richard, Treaty Interpretation, OUP 2015.

Gathii James, Mission Creep or a Search for Relevance: The East African Court of Justice's Human Rights Strategy, Duke Journal of Comparative \& International Law 2013/24.

Goldsmith Eric, Posner Jack, The Limits of International Law, OUP 2005.

Greenberg Udi, The Weimar Century: German Emigres and the Ideological Foundations of the Cold War, PUP 2015.

Hart Herbert Lionel A., Positivism and the Separation of Law and Morals, Harvard Law Review 1958/71(4).

Helfer Laurence R., Slaughter Anne-Marie, Why States Create International Tribunals: A Response to Professors Posner and Yoo, California Law Review 2005/93(3).

Hernández Gleider I., Impartiality and Bias at the International Court of Justice, Cambridge Journal of International and Comparative Law 2012/1(3).

Hernández Gleider I., The Judicialization of International Law: Reflections on the Empirical Turn, The European Journal of International Law 2014/25(3).

Jacobs Francis G., Varieties of Approach to Treaty Interpretation: with Special Reference to the Draft Convention on the Law of Treaties Before the Vienna Diplomatic Conference, International \& Comparative Law Quarterly 1969/18(2). 
Lauterpacht Hersch, Koskenniemi Martti, The Function of Law in the International Community, OUP 2011.

Letsas George, Strasbourg's Interpretive Ethic: Lessons for the International Lawyer, European Journal of International Law 2010/21(3).

Lixinski Lucas, Treaty Interpretation by the Inter-American Court of Human Rights: Expansionism at the Service of the Unity of International Law, European Journal of International Law 2010/21(3).

Meron Theodor, Judicial Independence and Impartiality in International Criminal Tribunals, American Journal of International Law 2005/99(2).

Morgenthau Hans J., Positivism, Functionalism, and International Law, American Journal of International Law 1940/34(2).

Murray Rachel, Decisions by the African Commission on Individual Communications Under the African Charter on Human and Peoples'Rights, International \& Comparative Law Quarterly 1997/46.

Mutua Makau, The African Human Rights Court: A Two-Legged Stool?, Human Rights Quarterly 1999/21.

Popovski Vesselin, International Rule of Law and Professional Ethics, Ashgate 2014.

Posner Eric, de Figueiredo Miguel F.P., Is the International Court of Justice Biased?, Journal of Legal Studies 2005/34.

Posner Eric, Yoo John C., Judicial Independence in International Tribunals, California Law Review 2005/ 93(1).

Remec Peter P., The Position of the Individual in International Law according to Grotius and Vattel, Springer Science \& Business Media 2012.

Romano Cesare P.R., Alter Karen J., Shany Yuval (eds.), The Oxford Handbook of International Adjudication, OUP 2013.

Settem Ola J., Applications of the 'Fair Hearing'Norm in ECHR Article 6(1) to Civil Proceedings: With Special Emphasis on the Balance Between Procedural Safeguards and Efficiency, Springer 2015.

Shelton Dinah (ed.), The Oxford Handbook of International Human Rights Law, OUP 2013.

Stemmet Andre, A Future African Court for Human and Peoples' Rights and Domestic Human Rights Norms, South African Yearbook of International Law 1998/23.

Sweet Alec S., Brunell Thomas L., Trustee Courts and the Judicialization of International Regimes: The Politics of Majoritarian Activism in the ECHR, the EU, and the WTO, Journal of Law and Courts 2013.

Udombana Nsongurua J., Toward the African Court on Human and Peoples'Rights: Better Late Than Never, Yale Human Rights and Development Journal 2000/3(1).

Vattel Emmerich de, Le Droit des gens, ou Principes de la loinaturelle: appliqués à la conduite et aux affaires des nations et des souverains, 1758, Book II.

Viljoen Frans, A Human Rights Court for Africa, and Africans, The Brooklyn Journal of International Law 2004/30(1).

Villiger Mark E., Commentary on the 1969 Vienna Convention on the Law of Treaties, Martinus Nijhoff Publishers 2009.

Williams Michael C., Realism Reconsidered: The Legacy of Hans Morgenthau in International Relations, OUP 2007. 
Marek WASIŃSKI

\section{REŻIM DEKLARACJI FAKULTATYWNYCH JAKO INSTRUMENT INTERAKCJI MIĘDZY PAŃSTWAMI I AFRYKAŃSKIM TRYBUNAŁEM PRAW CZŁOWIEKA}

(Streszczenie)

Dostęp jednostek do Afrykańskiego Trybunału Praw Człowieka jest ograniczony o tyle, że mogą one występować ze skargami jedynie przeciwko państwom, które złożyły stosowną deklarację fakultatywną. Artykuł dowodzi, że takie ograniczenie właściwości ratione personae sądu międzynarodowego może być traktowane jako rozwiązanie prowadzące do swoistego dialogu między Trybunałem a państwami afrykańskimi. W szczególności sędziowie Trybunału mogą świadomie stymulować procesy decyzyjne prowadzące do składania deklaracji fakultatywnych. W tym celu, w procesie interpretacji praw człowieka gwarantowanych w Karcie z Bandżulu, konieczne jest zachowanie równowagi między progresywną wykładnią pro homine a podejściem zachowawczym, zazwyczaj preferowanym przez państwa. Taka taktyka orzecznicza odzwierciedla szczególne cechy społeczności międzynarodowej, nie narusza bezstronności sędziowskiej oraz daje się pogodzić z normami prawa międzynarodowego o interpretacji traktatów.

Słowa kluczowe: prawa człowieka w Afryce; bezstronność sędziowska; niezawisłość trybunałów międzynarodowych 